\author{
ARTIKEL \\ CAMPUR KODE BAHASA SIMALUNGUN DALAM TULISAN \\ BERBAHASA INDONESIA SISWA KELAS VII SMP NEGERI \\ 1 PURBA TIGA RUNGGU TAHUN PEMBELAJARAN \\ 2016/2017 \\ Oleh \\ Vera Fewinda Saragih \\ NIM 2133311011
}

Dosen Pembimbing Skripsi

Dr. Abdurahman AS., M.Hum.

Telah Diverifikasi dan Dinyatakan Memenuhi Syarat untuk Diunggah pada Jurnal Online

Medan, Oktober 2017

Menyetujui :

Editor,

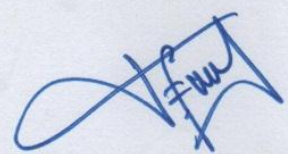

Fitriani Lubis, M.Pd.

NIP 197708312008122001
Dosen Pembimbing Skripsi,

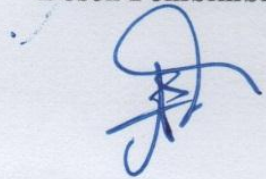

Dr. Abdurahman AS., M.Hum. NIP 196710011994031001 


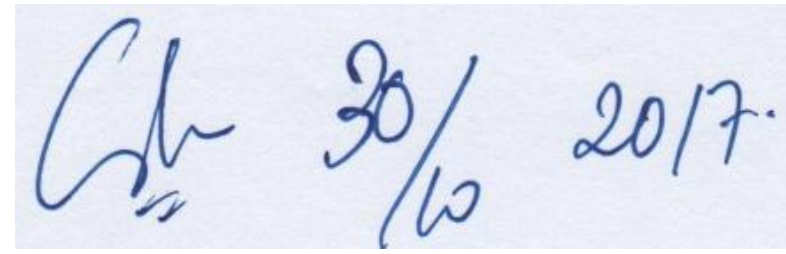

\title{
CAMPUR KODE BAHASA SIMALUNGUN DALAM TULISAN BERBAHASA \\ INDONESIA SISWA KELAS VII SMP NEGERI 1 PURBA TIGA RUNGGU
}

TAHUN PEMBELAJARAN 2016/2017

\author{
Oleh \\ Vera Fewinda Saragih (Verafewindasaragih12345@gmail.com) \\ Dr. Abdurahman AS.,M.Hum.
}

\begin{abstract}
ABSTRAK
Penelitian ini bertujuan untuk: (1) Indonesia siswa kelas VII SMP Negeri 1 Purba Tiga Runggu Tahun Pembelajaran 2016/2017, (2) Menentukan jenis campur kode bahasa Simalungun dalam tulisan berbahasa Indonesia siswa kelas VII SMP Negeri 1 Purba Tiga Runggu Tahun Pembelajaran 2016/2017.Adapun tulisan yang di teliti adalah tulisan berbahasa Indonesia siswa kelas VII. Hasil dari penelitian ini menunjukkan bahwa hasil data yang diperoleh oleh peneliti dari penelitian Peneliti menemukan terdapat bentuk campur kode dalam (1) bentuk kata, (2) bentuk frasa, (3) bentuk perulangan kata,dan (4) bentuk ungkapan/idiom. Bentuk campur kode dalam tulisan berbahasa Indonesia siswa kelas VII SMP Negeri 1 Purba Tiga Runggu Tahun Pembelajaran 2016/2017 sebanyak 205 kata dalam tulisan bentuk campur kode dari 30 data yang di dapat dari siswa. Dalam bentuk campur kode kata sebanyak 152 kata dalam tulisan campur kode Bahasa Simalungun. Bentuk Frasa sebanyak13 kata dalam tulisan campur kode bahasa Simalungun,Bentuk Ungkapan sebanyak 26 kata dalam tulisan campur kode bahasa Simalungun, dan Bentuk Perulangan kata sebanyak 14 kata dalam tulisan campur kode bahasa Simalungun. Suwito (2005:65). Ketiga jenis campur kode menurutnya antara lain adalah 1. Inner Code Mixing Campur kode yang dimaksudkan adalah campur kode yang menggunakan elemen-elemen dari bahasa asli atau bahasa asal campur kodenya yang masih terdapat hubungan dengan bahasa yang dicampur. 2. Outer Code Mixing jenis campur kode ini merupakan campur kode yang menggunakan elemen-elemen dari bahasa asing dalam peristiwa campur kodenya. Misalnya seorang penutur berbahasa Indonesia yang didalam komunikasinya menyisipkan elemen bahasa
\end{abstract}


asing 3.Hybrid Code Mixing Jenis campur kode yang dimaksud dapat menerima elemen apapun dalam peristiwa campur kodenya. Kata Kunci: campur kode, bahasa simalungun, tulisan berbahasa
indonesia

\section{PENDAHULUAN}

Pembelajaran bahasa mempunyai peran yang sangat penting, khususnya dalamdunia pendidikan.Bahasa merupakan alat komunikasi yang dibutuhkan manusia.Salah satu kunci sukses dalam berkomunikasi dengan menggunakan bahasa adalah ketepatan berbahasa.Tanpa bahasa manusia tidak dapat mengungkapkan segala yang ada dalam pikirannya.Oleh karena itu, bahasa merupakan alat komunikasi yang digunakan manusia dalam kehidupan sehari-harinya. Penggunaan bahasa yang tidak teratur akan menyulitkan pembaca atau pendengar untuk dapat memahami isi pesan yang akan disampaikan.

Pada arus globalisasi mempengaruhi seluruh seluruh aspek kehidupan. Pengaruh ini terlihat pada bidang pendidikan dan kebudayaan, salah satu yang akan di hadapi dunia pendidikan adalah masalah identitas bangsa. Pengaruh arus globalisasi dapat terlihat jelas dari sikap yang lebih mengutamakan bahasa daerah, juga bahasa asing dari pada bahasa Indonesia.Seseorang yang menguasai dua bahasa disebut bilingual(dalam bahasa Indonesia disebut juga dwibahasawan) sedangkan kemampuan untuk menggunakan dua bahasa disebut bilingualitas(dalam bahasa disebut juga kedwibahasawanan). Seorang dwibahasawan tentu tidak terlepas dari akibat penggunaan dua bahasa. Salah satu akibatnya adalah tumpang tindih antara 
dua sistem bahasa yang dipakai atau digunakannya dari unsur bahasa yang satu ke bahasa lain. Hal ini dapat terjadi karena penguasaan bahasa kedua oleh penutur atau bahkan kebiasaan.

Bahasa Indonesia merupakan salah satu mata pelajaran yang harus dikuasai dalam bidang pendidikan nasional. Sesuai dengan fungsi pendidikan nasional pembelajaran bahasa Indonesia bertujuan untuk mengembangkan warga Indonesia baik sebagai pribadi maupun sebagai anggota masyarakat, serta mampu mengembangkan fungsi bahasa dan kebudayaan. Pengajaran bahasa Indonesia bertujuan agar seseorang terampil menggunakan bahasa Indonesia dengan baik dan benar, baik lisan maupun tulisan. Pembelajaran bahasa Indonesia bertujuan memberikan pengetahuan kebahasaan agar murid mampu menguasai bahasa Indonesia sebaik-baiknya. Keterampilan berbahasa meliputi; keterampilan menyimak (listening skill)keterampilan berbicara (speaking skill), keterampilan membaca (reading skill), dan keterampilan menulis(writing skill).Pada penelitian ini keterampilan menulis digunakan untuk mencatat,melaporkan, dan mempengaruhi pembaca. Kemampuan menulis tidak secara otomatis dapat dikuasai oleh siswa, melainkan harus melalui latihan dan praktik yang banyak sehingga siswa akan lebih mudah berekspresi dalam kegiatan menulis.Dilihat dari hasil observasi yang dilakukan Putri Rahmadani (2015:7) dengan judul "Analisis Campur Kode pada Karangan Narasi Siswa kelas X MA Tanggerang. "Hasil penelitiannya menyatakan beberapa kesulitan utama yang dihadapi siswa dalam keterampilan menulis karangan 
eksposisi, yaitu: (1) kegiatan menulis di sekolah belum mendapat perhatian cukup dari siswa, (2) motivasi siswa terhadapi menulis masih rendah, karena siswa beranggapan bahwa menulis adalah kegiatan yang sulit dibandingkan keempat keterampilan berbahasa yang lain, (3) siswa kesulitan menemukan dan menuangkan ide dalam pembelajaran menulis, (4) model pembelajaran yang digunakan kurang menarik sehingga diperlukan model pembelajaran yang lebih menarik untuk meningkatkan minat siswa dalam menulis karangan eksposisi, dan (5) media yang digunakan kurang menarik perhatian siswa.Hasil penelitiannya adalah sebagai berikut jumlah keseluruhan penggunaan bentuk campur kode sebanyak 32 pada karangan eksposisi yaitu; bentuk kata,bentuk frasa, dan bentuk ungkapan,penggunaan jenis campur kode sebanyak 30 pada karangan eksposisi, yaitu; jenis campur kode outer code mixig (jenis campur kode yang berasal dari unsur bahasa asing maupun bahasa daerah). Berdasarkan uraian diatas, dapat disimpulkan bahwa untuk memperoleh hasil belajar yang diharapkan, maka dibutuhkan pemahaman yang memberikan pengalaman belajar bagi siswa untuk meningkatkan keterampilan berpikir kritis dan kreatif untuk menuangkan ide, gagasan pemikiran, pendapat, serta pemahaman dalam berbahasa baik dilingkungan formal maupun non formal. Pada penelitian ini pemahaman yang memfokuskan pada bentuk dan jenis campur kode bahasa Simalungun.Adapun judul yang dipilih sesuai dengan permasalahan tersebut adalah “Campur Kode Bahasa Simalungun dalam Tulisan Berbahasa Indonesia Siswa Kelas VII SMP Negeri 1 Purba Tiga Runggu Tahun Pembelajaran 2016/2017’. 


\section{METODE PENELITIAN}

Penelitian ini menggunakan metode deskriptif kualitatif.Artinya suatu metode penelitian untuk membuat suatu gambaran mengenai situasi atau kejadian untuk memperoleh kejelasan tentang data.

Metode penelitian ini berusaha menyajikan kenyataan-kenyataan secara objektif sesuai dengan kenyataan yang ditemukan dilapangan tentang penggunaan campur kode bahasa Simalungun oleh tulisan berbahasa Indonesia siswa. Meleong (2006:8) mengatakan bahwa metode kualitatif digunakan pada penelitian ini karena menguraikan fakta-fakta atau fenomena-fenomena penggunaan campur kode bentuk kata, gabungan kata atau kalimat dalam struktur yang benar.Penelitian dalam pengumpulan data menggunakan teknik observasi melalui teknik catat.Ketika dilakukannya teknik catat, narasumber tidak mengetahui bahwa peneliti telah mencari data-data yang berhubungan dengan campur kode.

\section{HASIL PENELITIAN DAN PEMBAHASAN}

\section{A. HASIL PENELITIAN}

\section{Bentuk Campur Kode}

Hasil data yang diperoleh oleh peneliti dari penelitian dengan judul Campur Kode Bahasa Simalungun Dalam Tulisan Berbahasa Indonesia Kelas VII SMP Negeri 1 Purba Tiga Runggu. Peneliti menemukan terdapat bentuk campur kode dalam bentuk kata, bentuk frasa, bentuk perulangan kata,dan bentuk ungkapan/idiom. Bentuk campur kode dalam tulisan berbahasa Indonesia siswa kelas VII SMP Negeri 
1 Purba Tiga Runggu Tahun Pembelajaran 2016/2017 sebanyak 205 kata dalam bentuk campur kode dari 30 data yang di dapat dari siswa. Dalam bentuk campur kode kata sebanyak 152 kata tulisan campur kode Bahasa Simalungun yakni:bentuk campur kode kata nomina sebanyak 51 kata bentuk campur kode Bahasa Simalungun, bentuk campur kode kata adjektiva sebanyak 33 kata dalam tulisan bentuk campur kode Bahasa Simalungun, bentuk campur kode verba sebanyak 61 kata dalam tulisan bentuk campur kode Bahasa Simalungun, bentuk campur kode adverbia sebanyak 3 kata dalam tulisan bentuk campur kode Bahasa Simalungun. Terdapat bentuk campur kode dalam bentukfrasa sebanyak 13 kata dalam tulisan bentuk campur kode Bahasa Simalungun, bentuk perulangan kata sebanyak26 kata dalam tulisan bentuk campur kode Bahasa Simalungun,dan bentuk ungkapan/idiom sebanyak 14 kata dalam tulisan bentukcampur kode Bahasa Simalungun. Bentuk campur kode dalam tulisan berbahasa Indonesia siswa kelas VII SMP Negeri 1 Purba Tiga Runggu Tahun Pembelajaran 2016/2017 sebanyak 205kata dalam tulisan bentuk campur kode dari 30 data yang di dapat dari siswa kelas VII-3 SMP Negeri 1 Purba Tiga Runggu Tahun Pembelajaran 2106/2017.

\section{Jenis Campur Kode}

Berdasarkan hasil penelitian, Jenis campur kode bahasa Simalungun dalam tulisan berbahasa Indonesia siswa kelas VII SMP Negeri 1 Purba Tiga Runggu dari hasil penlitian yang dilakukan peneliti dan dilihat dari data-data yang di kumpulkan bahwa campur kode bahasa Simalungun dalam tulisan berbahasa Indonesia Siswa 
kelas VII SMP Negeri 1 Purba Tiga Runggu tergolong dalam jenis campur kode Inner code mixing (Campur kode yang dimaksudkan adalah campur kode bahasa Simalungun antara bahasa Indonesia sebagai bahasa asal dalam peristiwa campur kodenya yang masih terdapat hubungan dengan bahasa yang dicampur)dari keseluruhan tulisan yang ditulis oleh siswa kelas VII-3 SMP Negeri 1 Purba Tiga Runggu Tahun Pembelajaran 2016/2017.

\section{B. PEMBAHASAN HASIL PENELITIAN}

\section{Pengertian bentuk campur kode}

Menurut Suwito (1996:92) ada beberapa bentuk campur kode yaitu:

a. Bentuk kata adalah bahasa terkecil yang membentuk kalimat Ino (2015:4). Kataterbagidua yaitu yang mengandung makna leksikal dan yang mengandung maknagramatikal atau makna struktural.

b. Bentuk frasaFrasa (dalam bahasa inggris phrase) adalah kesatuan bahasa yang lebih besar dari pada kata karena terdiri atas dua kata atau lebih. Chaer (1998:301) berpendapat bahwa frasa merupakan gabungan dua buah kata atau lebih yang merupakan kesatuan, dan menjadi salah satu unsur atau fungsi kalimat (subjek,predikat,objek, keterangan). Contoh: anak korban tabrak lari itu sudah dibawa ke rumah sakit.

c. Bentuk ungkapan atau idiom adalah "Pola-pola struktural yang menyimpang dari kaidah-kaidah bahasa yang umum, sedangkan artinya tidak dapat diterangkan secara 
logis atau secara gramatikal, dengan bertumpu pada makna kata yang membentuknya."

d. Bentuk unsur- unsur yang bersifat perulangan kata unsur yang berupa perulangan kata yang diambil dari bahasa lain yang disisipkan ke dalam kode dasar menyebabkan campur kode dalam interaksi sosial. Pengulangan tersebut dapat berupa pengulangan seluruh kata dasar, pengulangan sebagian dari dasar, dan pengulangan yang berkombinasi dengan proses pembubuhan afiks.

\section{Pengertian jenis campur kode}

Terdapat tiga jenis campur kode yang dikemukakan oleh Suwito (2005:65). Ketiga jenis campur kode menurutnya antara lain adalah sebagai berikut :

\section{Inner Code Mixing}

Campur kode yang dimaksudkan adalah campur kode yang menggunakan elemen-elemen dari bahasa asli atau bahasa asaldalam peristiwa campur kodenya yang masih terdapat hubungan dengan bahasa yang dicampur.

\section{Outer Code Mixing}

Jenis campur kode ini merupakan campur kode yang menggunakan elemenelemen dari bahasa asing dalam peristiwacampur kodenya. Misalnya seorang penutur berbahasa Indonesia yang didalam komunikasinya menyisipkan elemen bahasa Inggris, bahasa Belanda, dan lain sebagainya.

\section{Hybrid Code Mixing}


Jenis campur kode yang dimaksud dapat menerima elemen apapun dalam peristiwa campur kodenya, baik elemen bahasa asal ataupun elemen bahasa asing dalam kalimat atau klausanya.

\section{SIMPULAN DAN SARAN}

\section{A. SIMPULAN}

1. Terdapat jenis campur kode berupa campur kode campur kode kedalam (Inner Code Mixing) yang ditemukan dalam tulisan berbahasa Indonesia siswa kelas VII-3 SMP Negeri 1 Purba Tiga Runggu yaitu bahasa Simalungun dan bahasa Indonesia.

2. Terdapat bentuk campur kode dalam bentuk kata, bentuk frasa, bentuk perulangan kata,dan bentuk ungkapan/idiom. Bentuk campur kode dalam tulisan berbahasa Indonesia siswa kelas VII SMP Negeri 1 Purba Tiga Runggu Tahun Pembelajaran 2016/2017 sebanyak 205 kata dalam tulisan bentuk campur kode dari 30 data yang di dapat dari siswa.

\section{B. SARAN}

1. Bagi Mahasiswa Program Studi Pendidikan Bahasa dan Sastra Indonesia sebagai calon guru Bahasa Indonesia,dapat menjadikan hasil penelitian ini sebagai salah satu bahan diskusi pada mata kuliah Sosiolinguistik.

2. Apabila menulis dalam tulisan berbahasa Bahasa Indonesia hendaknya lebih baik kita menggunakan bahasa Indonesia untuk menghindari dari ketidaktahuan makna. 
3. Pada saat menulis dalam tulisan berbahasa bahasa Indonesia hendaknya kita memperhatikan bahasa yang kita gunakan agar pembaca mengetahui maksud dan pesan yang disampaikan.

\section{DAFTAR PUSTAKA}

Chaer, Abdul dan Leonie Agustina. 1995. Sosiolinguistik Perkenalan Awal. Jakarta: Rineka Cipta.

Meleong J.Lexi. 2006. Metode Penelitian Kualitatif .Bandung: PT Remaja Rosdakarya. Edisi Revisi.

Santosa, Made Hery. 2005. "Pemakaian Bahasa Pada Kelas Awal: Sebuah Observasi Mengenai Aspek-Aspek Kedwibahasaan Seorang Guru Bahasa Indonesia." Jurnal Pendidikan dan Kebudayaan, hlm 45-57. Jakarta: Badan Penelitian Pendidkan.

Suwito. 1983. Pengantar Awal Sosiolinguistik,Teori dan Problema. Surakarta: Henry Offset. 